Classified/Reading Ads: $\$ 1.00$ per word for 1 issue (15 words minimum); $\$ 75$ per word for each of 4 issues. Area code and phone number count as 2 words. Send ad with check or money order to JETTMART Classified Manager, 304C Moore College Building, UGA Language Laboratories, University of Georgia, Athens, Georgia 30602 U.S.A.

\section{JETTMART: Available}

Survey on Foreign Language Teaching Profession. Manhattan College researchers, Dr. Richard C. FitzPatrick and Dr. Anthony L. Liuzzo, have just publicized the results of a survey on the Foreign Language Teaching Profession. The survey, conducted with the endorsement and cooperation of the American Council on the Teaching of Foreign Languages (ACTFL) and the financial support of the Louis F. Capalbo Endowment Fund, concludes that male teachers of foreign languages are much more likely to be clustered in higher income brackets than are their female counterparts, both before and after adjustments for differences in years of experience. The authors also report that income is substantially influenced by several other factors, such as number of students in the institution (the greater the number, the higher the income), where the institution is located (suburban institutions pay the highest incomes), and geographic area of the country (Northeast is highest and South is lowest). For more details, contact: Anthony L. Liuzzo, Director of Business Research, Manhattan College, Riverdale, NY 10471.

1989 Equipment Directory.Completely updated and expanded, the latest edition of the New Equipment Directory of Audio-Visual, Computer \& Video Products is now available. The definitive reference for today's communications professionals, this directory puts complete details on state-of-the-art products on the market today at your fingertips. The book has over 200 categories of equipment with nearly 3000 products with over 400 manufacturers and 800 dealers represented. As the communications market expands to include more and more electronic equipment, so has this directory published by the non-profit trade association, The International Communications Industries Association (ICIA). The directory includes the following: video, audio, $A-V$, computer graphics equipment, multiimage, furniture \& storage systems, and learning systems, including language laboratories, reading devices, programmed instruction. The purchase price of the directory to ICIA members is $\$ 30.00$ per copy payment enclosed or $\$ 35$ per copy if billed. Nonmember price is $\$ 35.00$ per copy or $\$ 40$ per copy if billed. Send your order to ICIA, 3150 Spring Street, Fairfax, VA 22031-2399 or call (703) 273-7200.
Tape Tips. Revealed. Maxell Video Tape Handbook. Send self-addressed No. 10 envelope with $\$ .75$ postage to: Maxell Products Guide Offer, Box 4686, Reidsville, NC 27322-4686.

130 Courses in 47 Languages. Famous full-length courses developed for the U.S. Department of State. Introductory courses are available in the following languages: Amharic, Egyptian Arabic, Saudi Arabic, Moroccan Arabic, Eastern Arabic, Bulgarian, Cambodian, Chinese-Cantonese, Chinese-Manderin, Creole-Haitian, Danish, Dutch, Finnish, French, German, Greek, Hausa, Hebrew, Hungarian, Indonesian, Italian, Irish, Japanese Korean, Norwegian, Persian, Polish, Portuguese, Russian, Serbo-Croatian, Spanish, Swahili, Swedish, Tagalog, Thai, Twi, Urdu, Vietnamese, Welsh, Yoruba. Prices for these cassette programs range from $\$ 49-\$ 295.00$. They are available from Audio Forum, On-the-Green, Guilford, CT 06437 1-800-243-1234.

Mime Video Program.Speak Easy represents a new development in use of video for language learning. It aims to teach everyday conversational language through a combination of video, mime, and a variety of classroom activities. It can be used to teach any foreign or second language at any level. Each program consists of fourteen entertaining video mime sketches, 3-4 minutes each, involving two characters in real-life situations. The sketches enable students to make sense of a wide range of social encounters and transactions, to identify the communication needs of the participants concerned, and to discover the language required to respond to those needs. Speak Easy demonstrates language functions in action. Available in VHS, Beta, U-Matic. A Teacher's Manual is included with the video cassette. VHS/Beta-\$195, UMatic-\$215. Available from: Audio Forum, Suite C93, 96 Broad Street, Guilford, CT 06437 1-800-243-1234.

English as a Second Language on Video. Intermediate and advanced levels of ESL students who need to learn English for business, Bid for Power (intermediate) and The Bellcrest Story (advanced)each consisting of 13 fifteen minute programs, a selfstudy guide, and audio cassette-are now available in either 2 VHS or BETA video cassettes from: Audio Forum, On-the-Green, Guilford, CT 06437.

Augmenting Media Centers. Looking for free materials to augment your library or media center? The Free Ed Guide can help. Each quarterly issue includes listings of the following free resources: posters, videos, films, records, books, etc. Order your subscription today. One year of four issues costs $\$ 14.00$. Send order to: Free Ed Guide, 502 Woodside Avenue, Narberth, PA 19072. 
International Travel.If you are planning to travel abroad, you might be interested in purchasing the 1989 Centers for Disease Control's Health Information for the International Traveler for \$4.95. It's available from Superintendent of Documents, U.S. Government Printing Office, Washington, D.C. 20402. Put the publication number (017-023-00183-3) on your check or money order. Among other things, this handbook tells you where you are at greatest risk to pick up 34 diseases while you travel.

English to Chinese Characters by Computer.TianMa is an improved version of the leading Chinese text processing system used worldwide, that is, the famous TianMa. The new version allows the user to enter Chinese text in Romanization (Hanyu Pinyin) from a standard keyboard, or in Bopomofo (zhuyin fuhao) transcription; TianMa puts this phonetic input automatically into Chinese character text. IBM PC, XT, AT or compatibles, hard disk and graphics card. $\$ 695$ plus $\$ 20$ shipping. Contact: Audio Forum, On-theGreen, Guilford, CT 06437.
Panasonic Refunds. Are you among the 760,000 persons who bought any one of 16 Panasonic products during last year? You may be entitled to a refund, ranging from $\$ 15-\$ 50$. If you purchased a PV2800, PV2812, PV4800, PV4820, PV4860, PV4862, PV400, PV420, PV460, Panasonic answering machines and some Technics audio products (Technics is a Panasonic subsidiary), contact Panasonic for refund forms. If you filled out the warranty card, you will receive refund forms automatically (maybe?). Write. Refunds are due to a recent price-fixing settlement in New York involving Panasonic.

Confiscation. What will U.S. Customs confiscate when you return with "goodies" from abroad? Write to the Customs Service, 1301 Constitution Avenue, Washington, D.C. and ask for "Know Before You Go." It's free.

\section{If you can't take your students to Haiti, bring Haiti to them!}

\section{(via the Espace francophone series from PICS)}

The Espace francophone series offers twenty-five half-hour programs each on a different aspect of the francophone world. Selected titles include:

- Haîti, un peuple créateur

- Tunisie, un patrimoine au quotidien

- Fleuve Sénégal, un combat contre la mort

- Vanuatu, une francophonie menacée?
- Louisiane francophone

- Expressions québécoises

- Pacifique, l'avenir d'une francophonie

- Luxembourgeois, qui êtes-vous?

Espace francophone ("le magazine du monde d'expression française") is produced by ICAF (Institut pour la coopération francophone) and is available through PICS. Write or call now for our free catalogue of international video, both on videocassette and videodisc.

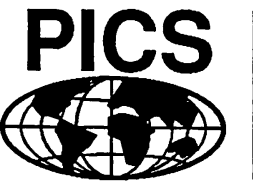

266 International Center The University of lowa lowa City, lowa 52242 1-800-373-PICS
Funded by The Annenberg/CPB Project 